\title{
Living with Difference: Experiences of Adolescents Subjected To Oral Facial Cleft Repair
}

\author{
Nandini. $\mathbf{M}^{1 *}$, Jayan. $\mathrm{C}^{2}$
}

\section{ABSTRACT}

Adolescents are best understood in a developmental context. The normal tasks of adolescent become complicated for the child with oral facial clefts. Existing multi specialty care is primarily aimed at physical rehabilitation with the psychological issues of care often being neglected. These articles address the biopsychosocial problems of adolescents with oral facial clefts who is experiencing adjustment problems. These articles also stress the need of a biopsychosocial intervention package for adolescence to assist in mastering the age appropriate developmental task.

Keywords: Adolescence ; Oral facial clefts ; Biopsychosocial intervention package.

Developmental tasks of adolescence can be broadly characterized as the evolution of a sense of personal identity and the achievement of independence. (Erikson,1963)The normal developmental tasks of adolescents include individuation from family development of sense of personal identity establishment of satisfactory peer relationship and body image. ${ }^{1}$ Research shows learning to live with a change in appearance of one's face as a result of injury/disease is a difficult tasks. ${ }^{2}$ The role of physical appearance has proved that a healthy physical appearance, regardless of facial or physical characteristics is considered attractive. Significant literature has shown in addition to coping with their physical appearance, adolescents with cleft anomaly in general have to deal with their more superficial psychological issues/psychological limitations. ${ }^{3}$ Thus this paper discuss about the various biopsychosocial issues among adolescents with oral facial clefts.

\section{Statement of the Problem}

A research critique on lived in experience of adolescents subjected to oral facial cleft repair, at Charles Pinto Centre, Jubilee Mission Medical College, Thrissur.

\footnotetext{
${ }^{1}$ Phd Scholar, School of Behavioural Sciences, MG University, Kottayam

2 Prof. HOD-Department of Psychology, University Of Calicut, Calicut

*Responding Author

(C) 2016 I M Nandini, C Jayan; licensee IJIP. This is an Open Access Research distributed under the terms of the Creative Commons Attribution License (http://creativecommons.org/licenses/by/2.0), which permits unrestricted use, distribution, and reproduction in any Medium, provided the original work is properly cited.
} 


\section{OBJECTIVES}

- Elicit the lived in experiences of adolescents before oral facial cleft repair

- Explore the lived in experiences of adolescents subjected to after oral facial cleft repair

- Extrapolate the various dimensions of the lived in experiences of adolescents subjected to oral facial cleft repair

\section{Purpose}

Develop an appropriate Biopsychosocial Intervention Package on Coping strategies for the adolescents subjected to Oral facial cleft repair

\section{Operational Definition}

Adolescents: Both the female and male adolescents in the age group of 12-21 years.

Lived in experience: Description on feeling and perception before and after the oral facial repair as verbalized by the adolescents

Oral facial cleft repair: Staged repair for the congenital anomaly of the face which includes cleft lip only, cleft palate only and cleft lip and palate

\section{Conceptual Framework}

Conceptual framework for the study was modified Peplau's interpersonal relation model.

\section{METHODOLOGY}

Design: Qualitative design with phenomenological approach

Setting: Charles Pinto Center at Jubilee Mission Medical College, Thrissur

Sample and sampling technique: Convenient sample of 20 adolescents admitted for Oral facial cleft repair.

\section{Sampling Criteria}

\section{Inclusion criteria:}

- $\quad$ Both the male and female adolescents within the age group of 12 to 20 years

- $\quad$ Adolescents who are able to speak and understand Malayalam

\section{Exclusion criteria:}

- $\quad$ Adolescents who are not willing to participate

- $\quad$ Adolescents who have Pierre Robin Syndrome

\section{Instruments}

A) Demographic data

B) Interview schedule with open ended questions

\section{Data Collection}

After obtaining permission from the concerned authority, the procedure for data collection was explained to the study participants. The informed consent was obtained from the samples to audiotape the interview. An in depth interview was conducted using an unstructured questionaire 


\section{Data Analysis}

Taped interview dialogue were listened to and transcribed in to verbatim. Thematic content analysis was done by Colaizzis analysis

\section{Modified Colaizzi Analysis Framework: -}

- The transcripts were converted in to formulated statements.

- Significant statement and phrases pertaining to the experience of patients under investigation were extracted

- Meanings of formulated statement and themes were identified

- Significant statements were organized in to clusters of themes

- The themes were used for exhaustive description

\section{Organisation of Findings / Transcribed Verbatim}

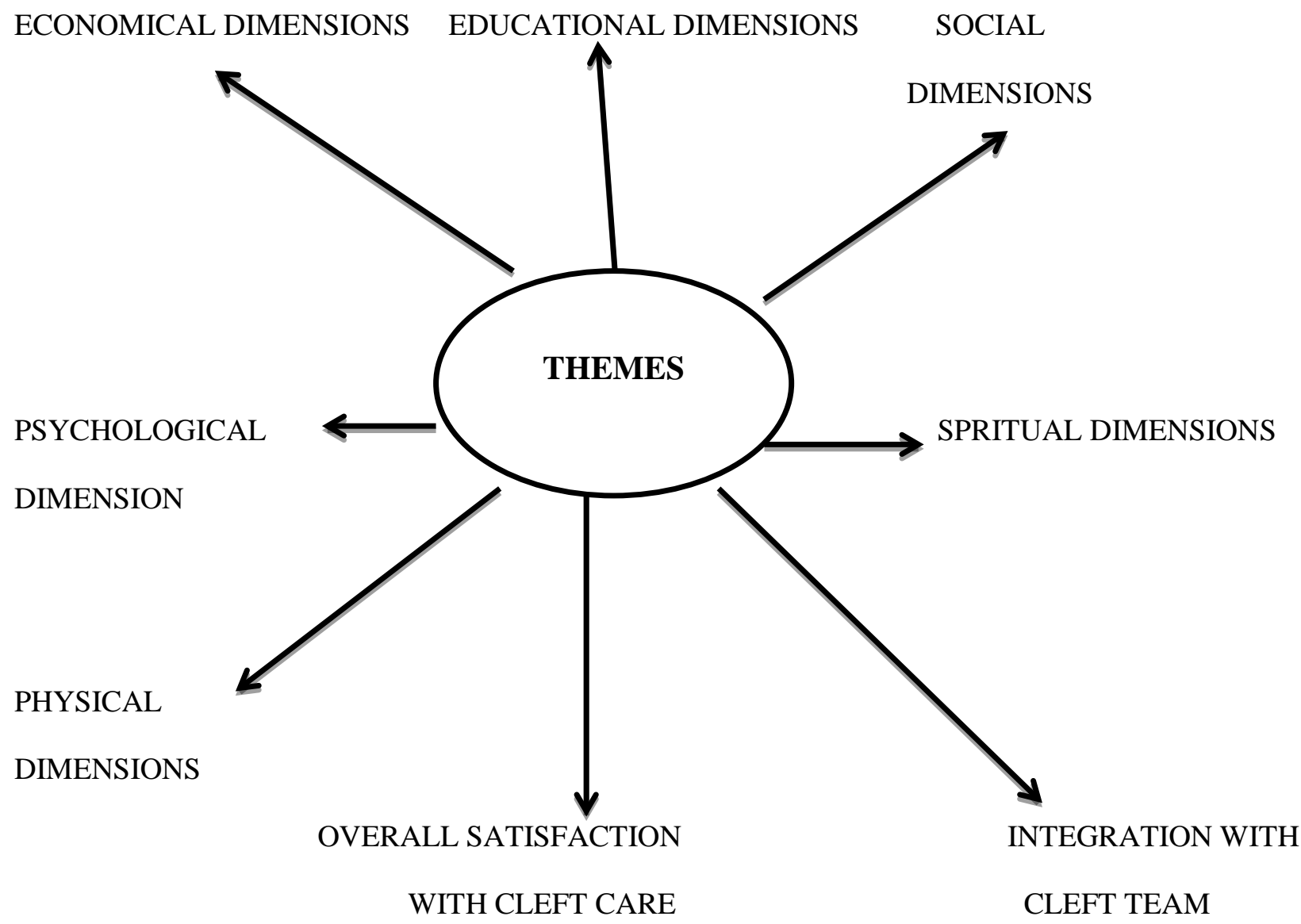

\section{PHYSICAL DIMENSIONS}

Preoperative experience

- “As I am worrying about my physical appearance I could not get sleep” 


\section{Living with Difference: Experiences of Adolescents Subjected To Oral Facial Cleft Repair}

- "I feel that I am unfit to achieve goal in my life due to this defect. So I am not able to sleep properly".

- "I am not able to take non vegetarian items especially ( chicken ) which I like most , due to the braces over the teeth

- "I will smile but I always wonder,oh, I have an ugly smile?

Post-operative experience

- "I am unable to sleep always due to throbbing pain”

- "I felt very difficult because I was always lying in the bed"

- " I was shocked when I recovered from anesthesia by seeing a tube in the nose, nasal package which totally covered my nose”

- Many times I shouted and screamed towards to my mother, because she only compelled me to undergo this last stage of surgery"

- I felt very tired, because I was advised to take only liquid diet”.

\section{PSYCHOLOGICAL DIMENSIONS}

Preoperative experience

- "It is hard to explain because a lot of times, I don’t care what people say about me"

- "I am always worried about my look and stuff. But then again, I don't really care what people think of me as long as $t$ am comfortable with who I am"

- "I am giving burden to my parents. In order to take me for therapy consultation , they have to take leave from job which causes financial constraints"

- I was so upset about my appearance. If my face comes to "normal" as like you. I can boldly look and talk to my friends.

\section{Post operative experience}

- When I think that I am going to get normal face, nose and lips I feel I am the luckiest person in this world

- Now I am praying to god, let this surgery be the last surgery on my face

- "I have seen another boy in the OPD in my same age who undergone the same surgery , But even after the surgery also his speech was not normal"

\section{ECONOMICAL DIMENSIONS}

\section{Preoperative experience}

- "If I attend the speech therapy regularly ( daily $1^{\text {st }}$ week )once in a week followed by this we will get the bus fare expenses from Charles Pinto Center"

- "My parents are very poor. They are spending lot of money towards to my treatment"

- Now I am 20 year old. My father expired at the age of 4 year. From my birth onwards my mother and grandmother is taking me to this hospital for consultation to correct my defect. This is my last stage of surgery. Oh! God ................"

\section{Post operative experience}

- I will go for job after my studies and I will support my father 


\section{Living with Difference: Experiences of Adolescents Subjected To Oral Facial Cleft Repair}

\section{EDUCATIONAL DIMENSIONS}

\section{Preoperative experiences}

- "I stopped by school education at upper primary level, because I was always teased by my friends”

- My teacher has provided emotional back up always which helped me to overcome the situations

- "I was good in singing. Ilike singing too but due to defect in speech I was excluded from the group song ; stating my sound is unique”

- "Now I am happy even though all my stages of surgery is over I know I have to come for regular follow up till my speech get clear"

\section{SOCIAL DIMENSIONS}

- “There are people in my school who don’t like me because I have a cleft lip and palate god knows why , I don't know”

- Constant starring and teasing lowered it (self-esteem) quite a bit .... Then it takes a while to bring it back up to know that you are not supposed to care what other people think

- "People will talk to you more when you look beautiful"

- “The facial difference, I guess it's made me more of a shy person, holding myself back from really getting to know people”

- "I always wonder what my life would be like if I was normal. But I don’t know I have to live with it so you might as well enjoy yourself"

- "I talk about my surgery with friends and with this surgery coming up , they want to come and visit me"

- "After surgery I will be more outgoing and that kind of things ; yeah I will be much more confident"

- "I found my group of friends and they stood up for me"

- I don’t really care what people think because I have my loving family

\section{SPIRITUAL DIMENSIONS}

\section{Preoperative experience}

- "I don’t know why god has created me like this"

- "While coming for each stage of surgery my parents will have offerings to god"

- "I am praying to god daily, let my speech be clear, and let me able to talk loudly as like others"

- "I don’t believe in worshiping god"

Post operative experience

- "By god's grace only all my stages of surgery came into success. After a one week of rest of vocal cord; I will be normal. I should be more thankful to god"

\section{INTERACTION WITH CLEFT TEAM}

- "I am very much satisfied with the cleft team"

- "Many times inconvenience of long journey to clinics overshadowed the purpose of appointment" 
- "I am getting discharge today after my last stage of surgery. Today cleft team has shown all my previous photographs with obvious facial defect. Even my parents don't have all the photographs of mine before the surgery. Thank to cleft team"

- "The effort by the speech therapist is highly appreciate"

- "The consoling words by the plastic surgeons and counseling session, homework by the speech therapist, orthodontic care, everything is standard and appreciable".

\section{OVERALL SATISFACTION WITH CLEFT CARE}

- "Here the doctors and sisters supported me and my family very well, which helps me to reduce my fear."

- "Today doctor came for rounds. He removed the dressing over my nose, I was little panic at that time you know! Finally he asked a mirror from my mother and he asked to look at my face in the mirror." Oh! God I was surprised to see my new nose. He said now "you look so beautiful.”

The subthemes extracted from the themes before and after oral facial cleft repair were as follows:

\begin{tabular}{|c|c|c|}
\hline THEMES & \multicolumn{2}{|c|}{ SUBTHEMES } \\
\hline & Pre-operative experience & \begin{tabular}{|l|l|} 
Post-operative experience \\
\end{tabular} \\
\hline Physical dimension & $\begin{array}{ll}\text { - } & \text { Sleep disturbance } \\
\text { - } & \text { Physical appearance } \\
\text { - } & \text { Not able to take diet properly }\end{array}$ & $\begin{array}{ll}\text { - } & \text { Pain } \\
\text { - } & \text { Sleep disturbance } \\
\text { - } & \text { Difficult in ADL } \\
\text { - } & \text { Fatigue }\end{array}$ \\
\hline Psychological dimension & $\begin{array}{ll}\text { - } & \text { Anxiety about the } \\
\text { appearance } \\
\text { - } & \text { Guilty feeling } \\
\text { - } & \begin{array}{l}\text { Anxiety about the outcome } \\
\text { of surgery }\end{array}\end{array}$ & $\begin{array}{ll}\text { - } & \text { Happiness } \\
\text { - } & \text { Fear about the outcome of } \\
\text { surgery }\end{array}$ \\
\hline Economical dimension & Economical burden & $\begin{array}{l}\text { Wish to earn money as early as } \\
\text { possible }\end{array}$ \\
\hline Educational dimension & $\begin{array}{l}\text { Discontinued from studies } \\
\text { due to this defect }\end{array}$ & \\
\hline Social dimension & $\begin{array}{ll}\text { - } & \text { Peer support } \\
\text { - } & \text { Family support } \\
\text { - } & \text { Inability to meet other }\end{array}$ & \\
\hline Spiritual dimension & - Blaming God & Thankful to God \\
\hline Interaction with cleft team & $\begin{array}{ll}\text { - } & \text { Much satisfied } \\
\text { - } & \text { Long journey to reach to } \\
\text { clinic } \\
\text { - } & \text { Emotional support }\end{array}$ & \\
\hline $\begin{array}{l}\text { Overall satisfaction with } \\
\text { cleft care }\end{array}$ & Satisfactory & \\
\hline
\end{tabular}




\section{DISCUSSION}

In this study 20 interviews were carried out among adolescents subjected to oral facial cleft repair. There were 2 broad aims to this study.

Totally 8 themes were identified in the analysis such as physical dimensions, psychological dimensions, economical, educational, social, spiritual, interaction with cleft team and overall satisfaction with client care. Body image disturbances, sleep disturbance, pain in the post operative period, feeling fatigue were the physical discomfort experienced by the samples, whereas 2 subjects did not experience sleep disturbances. Although adolescents seem relatively satisfied with their body image, some features specifically associated with oral facial clefts such as nose and teeth are considered less than satisfactory and may result in problems with body image. Few adolescents are dissatisfied with their speech. However, those with concerns regarding facial appearance are also more likely to have concerns regarding speech. Social isolation from peers, due to poor speech was obviously identified. During interviews one of the mother of a 15 year old adolescent reported that her child is 'shy' although she is unsure whether this was due to 'cleft', or just a teenage phase. During the interview, investigator identified adolescents and their parents invest a great deal of emotional and physical effort in to their child's cleft care. The passage of time, coupled with current expressions of satisfaction, may mask the painful feelings associated with past experiences. Emotional needs of these adolescents should be taken care in order to promote coping strategies. The investigator was able to find out that each adolescent is unique and experience and perception varies from adolescent to adolescent. Nurses as health professionals needs to intensify their involvement in implementing the care to enhance the supportive environment and to reduce the stress of adolescents with oral facial cleft before and after surgery.

\section{CONCLUSION}

The study was conducted to explore the lived in experience of adolescents subjected to oral facial cleft repair has been carried out using interview schedule.

- Despite high level of expressed satisfaction for clinical outcome, majority of subjects perceived self confidence had been very much affected as a result of their cleft.

- This qualitative study demonstrated a clear need for a biopsychological assessment to be routinely incorporated into existing cleft care programmes.

- This assessment would specifically identify individuals for whom counseling or social skills training would be of benefit.

- The rehabilitation of oral facial cleft adolescents should address psychological outcome as well as clinical outcome.

\section{REFERENCES}

Avinash De Sousa, ShibaniDevare and Jyoti Ghanshani. Psychological issues in Cleft lip and Cleft palate. Journal of Indian Association of Pediatric Surgeons.2009.April-June 14 (2),55-58. 


\section{Living with Difference: Experiences of Adolescents Subjected To Oral Facial Cleft Repair}

Feragen KB, Rumsey N, Borge AIH. (2010) Adolescent with and without a facial difference : the role of friendship and social acceptance. Journal of Body Image; 7: 271-279.

Gussy M, Kilpatrick N. (2006) The self concept of adolescents with cleft lip and palate: a pilot study using a multi dimensional/hiearrachial measurement instrument. International Journal of Pediatric Dentistry; 16: 335-341.

Kapp Simon KA, Simon DJ, Kristouich S. (1992) Self perception, social skills, adjustments and inhibition in young adolescents with craniofacial anomalies. Cleft Palate Craniofacial Journal; 29: 352-356.

Kasuya M, Sawaki Y, Ohno Y, Veda M. (2000) Psychological study of cleft palate children with or without cleft by kinetic family drawing. Journal of Cranio maxillo facial surgery; 28: 373-379.

Kathleen.A.Kapp Simon. Psychological Interventions for the adolescents with cleft lip and palate.Cleft Plate Craniofacial journal 1995;32:104-108.

Mercer PW, Merrit SL, Cowell ED. (1998) Differences in reported sleep need among adolescents. Journal of Adolescent Health; 23: 259-263.

Rankin M,Borah G. Perceived functional impact of abnormal facial appearance. Plastic Reconstructive Surgery.2003;111.

Van Manen M. (1997) Researching lived experience , $2^{\text {nd }}$ ed. London, Ontario: The Althouse Press. 